\title{
REP-LECOTOX: an example of FP 6 INCO project to strengthen ecotoxicological research in WBC (Western Balkan countries)
}

\author{
Ivana Teodorović, Sonja Kaišarević, Kristina Pogrmić-Majkić, Ivana Planojević, Svetlana Fa, Vanja Dakić, \\ Jelena Hrubik, Branka Glišić, Radmila Kovačević
}

\begin{abstract}
REP-LECOTOX project - INCO-CT-2006-043559-REP-LECOTOX UNSPMF - Reinforcement of research potential of Laboratory for Ecotoxicology (LECOTOX) of University of Novi Sad Faculty of Sciences funded by EC FP6 (20072009) presented a crucial milestone for LECOTOX, both in terms of overall research performance and its visibility and presentation to international scientific community. The project enabled upgrading and renewal of S\&T equipment, hiring new young researchers to reinforce human resources and it facilitated extensive networking - via workshops, exchange of scientific personnel and trainings of young scientists in some of the finest research institutions in the EU in the field of environmental research: Helmholtz Centre for Environmental Research - UFZ, Leipzig, Germany; School of Bioscience, University of Birmingham, UK and RECETOX, Masaryk University, Brno, Czech Republic. The project enabled LECOTOX, focusing mainly on two research topics, i.e. endocrine disruption/ reproductive toxicity, and identification and characterisation of aquatic toxicity, to form a functional competitive research team ready for combining transcriptomics with the established conventional toxicity tests and traditional function-based biomarkers. LECOTOX became well-equipped and experienced research group confident enough to join any FP or otherwise funded ecotoxicological research project and network.
\end{abstract}

\begin{abstract}
About LECOTOX - laboratory for ecotoxicology at UNSPMF

LECOTOX - Laboratory for Ecotoxicology at the Department of Biology and Ecology at University of Novi Sad Faculty of Sciences was formally established in 2006 as the result of intention to overcome the former fragmentation of the groups focusing on (eco) toxicological research since the mid 1990s. Relying on years of high-quality research in the field of animal physiology, specifically in reproductive endocrinology e.g. [1-9], the activities of LECOTOX researchers were (and still are) focused on toxic impact of persistent organic pollutants (POPs) on biota with special emphasis on specific sublethal types of toxicity - endocrine disruption, reproductive toxicity, and "dioxin-like" toxicity [10-16]. Bio analyses based on molecular and cellular biomarkers of
\end{abstract}

\footnotetext{
* Correspondence: teodorovic@beocity.net Department of Biology and Ecology, LECOTOX - Laboratory for Ecotoxicology, University of Novi Sad Faculty of Sciences, Trg Dositeja Obradovića 2, 21000 Novi Sad, Serbia
}

effects, such as cytochrome P450 (CYP) enzyme induction and parameters and markers of oxidative stress and early intoxication have been applied in assessment of freshwater ecosystems e.g. [17]. In close co-operation with the Department of Chemistry, Biochemistry and Environmental Protection, the Laboratory of Ecotoxicology applies aquatic toxicity tests for effluent and ambient water quality assessment and environmental impact assessment for remediation activities on contaminated sediments and soilse.g. [18-20]. A big step forward related to ecotoxicological research was reflected in participation in the APOPSBAL project (Assessment of the selected POPs (PCBs, PCDD/Fs, POCPs) in the Atmosphere and Water Ecosystems from Waste Materials Generated by Warfare in the Area of Former Yugoslavia, FP5-ICA2-CT-2002-10007, 2002 - 2005). The combination of chemical and biological tools (micro-EROD analysis in the first place) was used to estimate the toxicity of sediment samples from three rivers located at Kragujevac hotspot (Serbia) [21], soil and sediment samples

\section{SpringerOpen ${ }^{\circ}$}

(c) 2011 Teodorovićć et al; licensee Springer. This is an Open Access article distributed under the terms of the Creative Commons Attribution License (http://creativecommons.org/licenses/by/2.0), which permits unrestricted use, distribution, and reproduction in any medium, provided the original work is properly cited. 
from the area of Zadar, Croatia [22], and soil from oil refineries and petrochemical plant in Vojvodina (Serbia) after the NATO campaign spills [23,24].

\section{REP-LECOTOX project - reinforcement of research potential of LECOTOX}

FP 6 INCO Programme was an ideal opportunity for the established but suboptimally equipped research groups from new, candidate and non-EU member countries to fully integrate into the international scientific community. The overall aim of the Capacities Programme is to enhance research and innovation throughout Europe by optimising research infrastructure, enhancing research potential of European convergence and outermost regions, and building strategic $R \& D$ partnerships with non-EU countries. A LECOTOX team, led by the head of laboratory, Prof. Dr. Radmila Kovačević, recognised that unique chance and prepared a project proposal for FP6 INCO-2005-C-WBC SSA call for reinforcement of the WBC research capacities launched in 2006. REPLECOTOX is an acronym for the project INCO-2005C-WBC 043559 - REP-LECOTOX "Reinforcement of Research Potential of the Laboratory for Ecotoxicology". Having recognised the great potential of "omic" methods in ecotoxicological research and risk assessment, LECOTOX team made an initial step towards application of genomics-based tools in ecotoxicology, aiming to combine transcriptomics with established conventional toxicity tests and traditional function-based biomarkers.

The overall aim of the project was to strengthen research capacities and potential of the Laboratory for Ecotoxicology at the University of Novi Sad Faculty of Sciences, Serbia and to facilitate introduction and application of genomics-based tools as a prerequisite for the laboratory's long-term strategic orientation towards one of the most promising fields of environmental research today - ecotoxicogenomics.

The major REP-LECOTOX objectives were to: (a) upgrade and renew equipment, (b) reinforce human potential and (c) expand international collaboration and networking. Four outstanding EU institutions have supported the project by offering their expertise and highquality trainings for LECOTOX young researchers: (1) Centre for Environmental Research - UFZ, Leipzig, Germany; (2) RECETOX, Masaryk University, Brno, Czech Republic; (3) School of Biosciences, The University of Birmingham, Edgbaston, Birmingham, UK and (4) Department of Animal Physiological Ecology, Zoological Institute, University of Tübingen, Germany. The International Scientific Advisory Board (ISAB) consisted of the representatives of partnering institutions: Dr. Werner Brack (UFZ), Prof. Dr. James Kevin Chipman (The University of Birmingham), Prof. Dr. Ivan Holoubek (RECETOX) and Prof. Dr. Heinz-R. Koehler
(University of Tübingen). To facilitate efficient implementation of the project, the activities have been divided into five work packages: mobility and training, dissemination of information, organisation of the workshops, reinforcement of LECOTOX and Management.

\section{Reinforcement of LECOTOX}

The measurement of gene expression levels upon exposure to a chemical can be used both to provide mechanistic knowledge of the genetic basis of toxic effect and to form a sort of "genetic signature" for identification of toxic product. Real-time PCR allows accurate quantification of starting amounts of DNA, cDNA and RNA targets. This is in contrast with the end point detection in conventional PCR, which does not enable accurate quantification of nucleic acids. Therefore, the reinforcement of LECOTOX in terms of equipment included procurement of 7900HT FAST REAL-TIME PCR System consisting of standard hardware configuration (with a standard 96-well block) and computer with Sequence Detection Software, Primer Express Oligonucleotide Design Software and monitor. The upgrade of the system configuration consists of TaqMan low-density array, 384-well microfluidic cards designed for analysing gene expression patterns in many samples across a defined set of gene targets. For sample preparation, the system is accompanied by centrifuge supplied with rotor and adapter for fluidic cards. The laboratory was supplemented also with additional fast thermal cycler with a 96-well block module for parallel running of simple PCR when necessary (Figure 1).

Another important aspect of reinforcement was the selection of young research trainees to be hired for REP-LECOTOX project. Apart from three research trainees hired according to the plan, another three parttime research trainees - PhD students who had been granted the full scholarship by the Ministry of Science and Technological Development of the Republic of Serbia - were co-funded by the REP-LECOTOX project and included into all ongoing activities during the course of the project. All three full-time and three parttime research trainees progressed as planned during project implementation.

\section{Mobility and trainings}

During the project implementation, eleven trainings for young researchers were organised in three partnering institutions. Eleven short-term visits of LECOTOX senior and junior scientist to partnering institutions and ten return visits (researchers from partnering EU institutions to LECOTOX) were organised during REP-LECOTOX workshops.

Two Departments of UFZ Leipzig - Department of Effect-Directed Analysis (EDA) lead by Dr. Werner 


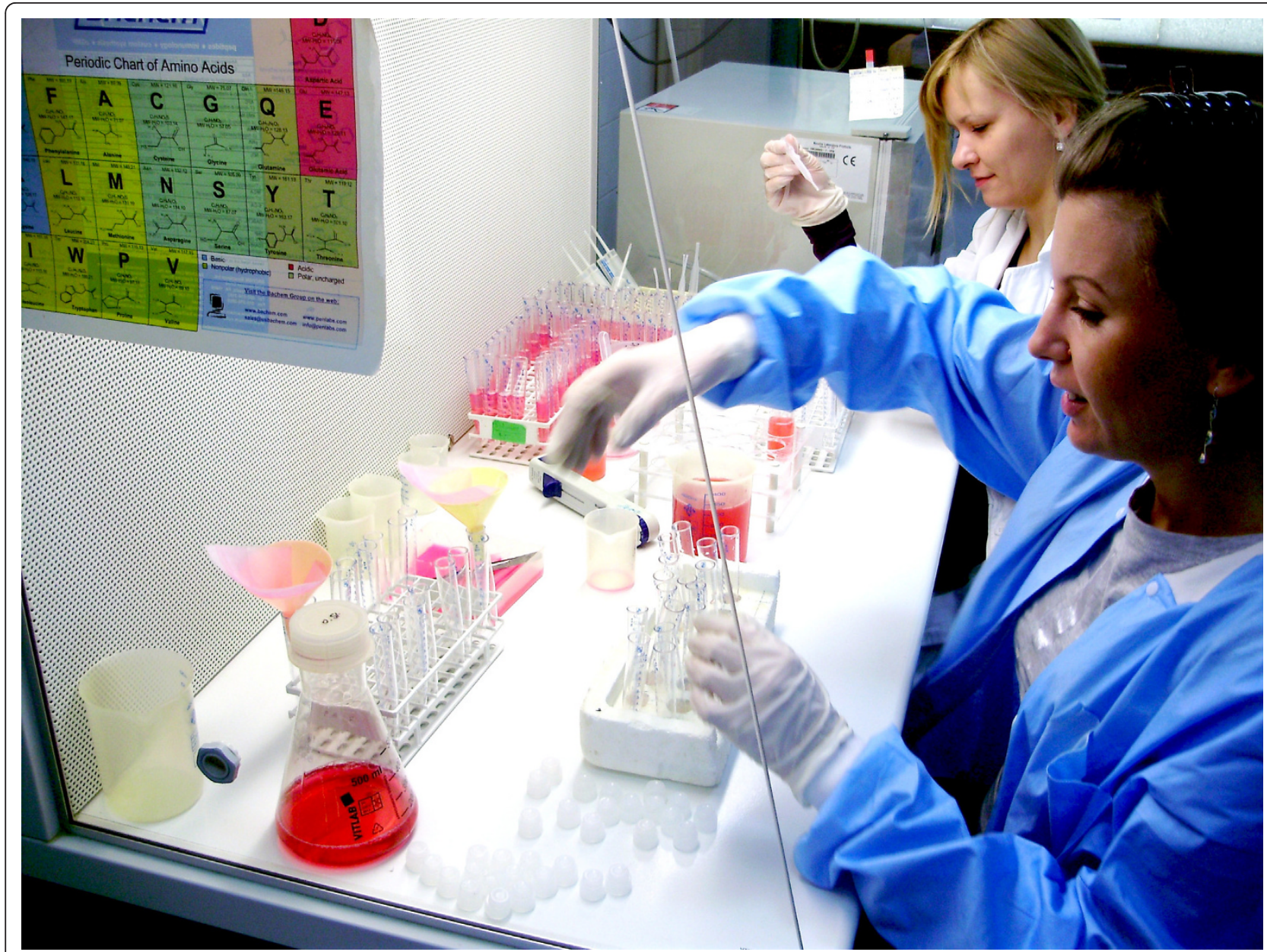

Figure 1 REP-LECOTOX research trainees

Brack and Department of Bioanalytical Ecotoxicology (former Department of Cell Toxicology) lead by Dr. Stefan Scholz - provided trainings for REP-LECOTOX research trainees and hosted LECOTOX senior and junior scientists during the project implementation.

Dr. Brack, with his EDA research group, focuses on developing tools for precise detection of key environmental (mainly aquatic) toxic pollutants, as well as methods and models for ecological risk assessment and environmental monitoring based on the observed biological effects. Therefore, the Department of EDA hosted both biologists and chemists from the UNSPMF, as building up a competent, coherent inter and multidisciplinary team is a prerequisite for implementation of a complex, tiered EDA approach, which, as the currently best recognised method in risk assessment of complex environmental matrices was the ultimate goal for LECOTOX. Since LECOTOX was already incapacitated and experienced in conducting a great variety of toxicity tests and bioassays applied in EDA, the trainings in UFZ included hands-on tool in fractionation of sediment samples by pressurised liquid extraction and accelerated membrane-assisted cleanup [25], followed by an automated multistep online fractionation procedure on three coupled normal phase HPLC columns [26], automated online fractionation procedure on return phase HPLC and qualitative analysis of semi-volatile pollutants by means of gas chromatography-mass spectrometry operating in scan an SIM mode, in conjunction with appropriate data analysis applications and chemometric tools.

Dr. Scholz, with his research group within the Department of Bioanalytical Ecotoxicology, focuses on developing alternative ecotoxicological methods which would eventually replace whole animal testing (in line with the current trends) and ecotoxicogenomics; the group already has a respectful record of application of genomicbased tools (mainly transcriptomics) in researches on mode of action of a wide range of xenobiotics. The research interest of Dr. Scholz and his group directly corroborates with the main objectives of the REP-LECOTOX project, namely, the trainings organised there directly helped the introduction of ecotoxicogenomics into 
laboratory practice of LECOTOX and diversification of in vitro methods on widely recognised but also new promising biological models. The aim of the trainings was to get familiar with fish embryo toxicity test (DarT) and geneDarT test - alternatives to acute toxicity tests on fish, process of dechorionation of Danio rerio embryos (used for testing toxic substances whose action is blocked by chorion), process of microinjection (used to input specific substances in unicellular stage embryos) and development of Danio rerio testis tissue culture - as such system could be used for testing endocrine disrupting substances.

The ecotoxicological division of RECETOX represents one of the research units well-known in Europe for a high diversity of in vivo and in vitro ecotoxicological tests, routinely performed in research and for monitoring purposes. As one of the goals of REP-LECOTOX project was also to build up research potential by introduction of several new in vivo ecotoxicological test methods, the purpose of the trainings hosted by two research groups - AQUATOX (supervised by Dr. Ludek Blaha and Dr. Klara Hilschlerova) and SOILTOX (supervised by Dr. Jakub Hofman) - was to get know-how in several aquatic and terrestrial acute and chronic toxicity tests using Vibrio fischeri, Pseudokirchneriella subcapitata, Caenorhabditis elegans, Lactuca sativa, Folsomia candida and Enchytraeus albidus.

The School of Biosciences, University of Birmingham, Edgbaston, Birmingham, UK - the research institution with sophisticated equipment and competent specialists (lead by Prof. Chipman) in the field of transcriptomics, techniques widely used in ecotoxicology and toxicology for measuring effects of stressors and understanding mechanism of their toxicity - was a perfect place to gain theoretical and practical knowledge, applicable to the planned research activities of LECOTOX. The trainings focused on gene expression analysis by qRTPCR of some key responding genes of Daphnia magna after treatment with benzo (a) pyrene and sodium dichromate. As the first step, gene expression was checked upon using microarray, which is the main tool for global gene expression profiling of the response of an organism in a particular condition. However, expression levels of key responding genes of the microarray need to be validated by real-time PCR. This study was a part of a bigger project aiming at the development of 'omic'-based methods using Daphnia magna as a tool for monitoring the effects of toxic agents in the environment.

The exchange and mobility at the level of permanent, senior, and junior staff of LECOTOX and partnering institutions was very well balanced. In total, 11 visits of LECOTOX scientists to partnering institutions and ten return visits were organised during implementation of the projects. LECOTOX members' visits to partner institutions were mainly aimed at detailed planning of the young research trainees, REP-LECOTOX workshop preparations and discussions on further co-operation opportunities. LECOTOX scientists were able to visit the research laboratories, get familiar with the state-ofthe-art equipment, laboratory organisation and see and adopt the principles of good research management. Those visits also facilitated further networking and creation of very tight personal contacts with hosts. On the other hand, the return short-term visits of the researchers from partnering institutions to LECOTOX were mainly organised during two REP-LECOTOX workshops: the experts from UFZ (Dr. Werner Brack, Dr. Stefan Scholz and Dr. Mikhail Beketov), RECETOX (Dr. Ivan Holoubek, Dr. Ludek Blaha, Dr. Klara Hilscherova and Dr. Jakub Hofman) and School of Biosciences (Dr. James Kevin Chipman) participated as keynote speakers and invited lecturers at both events. Moreover, the scientists from partnering institutions, particularly ISAB members, used the visits to inspect the progress of the REP-LECOTOX project, to visit research facilities at LECOTOX as well as other research groups at UNSPMF, meet other researchers and management structure and open the gate for potential further collaboration beyond REP-LECOTOX project.

\section{REP-LECOTOX workshops}

The main objective of the first REP-LECOTOX workshop: "Ecotoxicogenomics: the challenge of integrating genomics/proteomics/metabolomics into aquatic and terrestrial ecotoxicology", Novi Sad, June 15 to 18, 2008 was to bring together experts in the field of genomics, transcriptomics, proteomics, metabolomics and bioinformatics as invited speakers to the workshop in order to get a comprehensive overview of the state-of-the-art ecotoxicogenomics and implementation of omic technologies in the field of ecotoxicology. Workshop participants had the opportunity to learn about trends in ecotoxicogenomics from five plenary and six topic-specific presentations of recognised experts in each specific field (presentation available on LECOTOX Web pages). The last two days of the workshop were devoted to laboratory demonstrations of the 7900HT Fast RealTime PCR system (Applied Biosystems) and 2100 Bioanalyzer (Agilent). The comprehensive workshop report is published in ESPR [27].

The second REP-LECOTOX workshop: "Trends in Ecological Risk Assessment", Novi Sad, September 21 to 23, 2009 was aimed at presenting comprehensive information about the current state, challenges and trends in the field of ecological risk assessment, with special reference to application into environmental management practice and providing local and regional professionals, decision makers, and different stakeholders (industry, 
regulatory agencies, academia) with a broad overview of the current EU regulations and future trends regarding risk assessment of chemicals and ecological risk assessment (with special reference to REACH and WFD). The workshop scientific programme was structured into two large sessions: (1) risk assessment of chemicals with special attention to REACH (divided according to topics into three subsessions, (a) legislative aspect; (b) emerging substances and nanomaterials: analyses, environmental fate, effects, ERA; and (c) incorporating omic information into risk assessment and policy) and (2) ecosystem risk assessment (divided into three subsessions: (a) aquatic ecosystems, ERA in WFD and GD; (b) special ERA topic - upscaling and (c) terrestrial ecosystems). Two keynote lecturers and even 18 invited speakers from well-known European research institutions were invited to present extremely diverse ERA topics, ranging from case studies to conceptual frameworks and opinion statements (presentations available at project's homepage). To enable further exchange of experiences and information about the research potential and capacities of local (Serbian) and regional research institutions and teams, seven workshop participants were invited to present the results of their current work in the form of short oral presentations while others were invited to present posters. A comprehensive report is accepted for publication in ESEU [28].

\section{Dissemination of information}

The most important milestone in dissemination of information about the LECOTOX and REP-LECOTOX project was launching of the Web portal http://www. lecotox.net. Other important activities included publications in scientific [27-29], and popular [30-32], journals, participation in various scientific meetings and other events and press releases. LECOTOX members promoted REP-LECOTOX project, as well as the results of recent and ongoing research projects of the group at the important international scientific conferences (SETAC EUROPE 2008, 2010; FEBS 2008; PRIMO 2009; IUBMB/FAOBMB 2008; ICCE 2009; SIL 2007; IAD 2008, 2010), workshops (MODELKEY 2009, RISKBASE 2009, COST Action 636 Xenobiotics in Urban Water Cycle 2007-2008, EuLemnos 2009) and round tables (SedNet 2009). Promotional material (flyers, leaflets available for download from the home page as well as the project compendium - see Additional file 1) and all the above-mentioned events were used for further networking and promotion of LECOTOX as a suitable competitive and competent partner for future research projects within the FP and beyond. REP-LECOTOX project and other activities of LECOTOX were presented to a wide national public via press releases in printed (three articles in regional newspapers) and electronic media (interviews of senior LECOTOX members for the radio and TV, talk show at regional TV, footage from the openings of the REP-LECOTOX workshops, Web resources).

\section{REP-LECOTOX project outcomes and follow-up}

The fully operational 7900HT Fast Real-Time PCR system has already yielded with results although its overall scientific output is only to be expected through activities of LECOTOX in ongoing and future research projects. Knowledge, new methods and know-how gained via trainings in partner institutions were transferred to LECOTOX and incorporated into individual research activities of young researchers in the form of MSc and $\mathrm{PhD}$ theses (completed and those in progress) and peer reviewed publications in scientific journals. Equally important, modern EDA and sediment TRIAD approach, new equipment, techniques, expertise and newly introduced in vivo and in vitro toxicity tests have already been applied directly into MSc and PhD level education at the Department of Biology and Ecology. Intensive networking with partnering institutions and individual researchers facilitated, in the first place, highly professional organisation of two workshops of outstanding scientific performance, while the workshops themselves were used not only for getting acquainted with state-of-the-art techniques in ecotoxicogenomics and risk assessment, but for further networking and scientific exchange. Besides its scientific and educational goals, the upgraded and strengthened LECOTOX will have an important task in the future, as well as the capability and capacity to offer its expertise and advice to policy and decision makers as well as to various stakeholders. One of such examples certainly is a project "Chemicals Risk Management in Serbia", funded by the Republic of Serbia, Ministry of Environment and Spatial Planning and Swedish Chemical Agency. (REACH, Part C Ecotoxicological methods, consultant I. Teodorovic, LECOTOX). I. Teodorovic serves currently as a member of the Commission in National Authority for Plant Protection Products registration; Republic of Serbia, Ministry of Agriculture, Forestry and Water Management and a member of the Commission in National Authority for Biocidal Products registration, Republic of Serbia, Ministry of Environment and Spatial Planning, Chemical Agency.

The project itself, as specified by the INCO programme, was not intended to be research, but was strictly capacity building-oriented. Therefore, apart from immediate impact and direct project outcomes presented above, the successful implementation of the project represented a qualitative step forward in research and educational performance of LECOTOX. In January 2006, LECOTOX launched a 5 -year project focusing on EDCs 
(BFRs, PCBs, PAHs and pesticides) and their effects on reproductive and thyroid function, environmental assessment and bioanalyses, (project no. 143058, funded by the Ministry of Science and Technological Development of the Republic of Serbia). The results of the project, thanks to newly introduced omic tools (transcriptomics) provided better insight into mechanisms of adverse effects of atrazine (Figure 2) [33,34], and BFRs [35] on peripubertal rat Leydig cell steroidogenesis.

As a follow-up of high-quality trainings, in close cooperation with UFZ, Leipzig, EDA approach, combining highly sophisticated chemical tools with specific biomarkers of exposure (CYP enzyme induction and cell proliferation) was successfully implemented (Figure 3) at
Pančevo hotspot (Serbia) for identification of key sediment toxic pollutants $[36,37]$.

The know-how gained via trainings and cooperation with RECETOX, Brno, resulted in successful application of newly introduced tests in laboratory scale research [38] and complex sediment TRIAD assessment at Pančevo hotspot (Serbia) [39]. The results of the study that was carried out during the trainings organised at University of Birmingham, focusing on gene expression in neonate and adult daphnids in relation to relative susceptibility to genotoxicants, are in the final stage of preparation for publication [40]. The expertise gained via trainings in UFZ, Leipzig enabled LECOTOX to get sufficient financial support from the Secretariat for Science and Technological
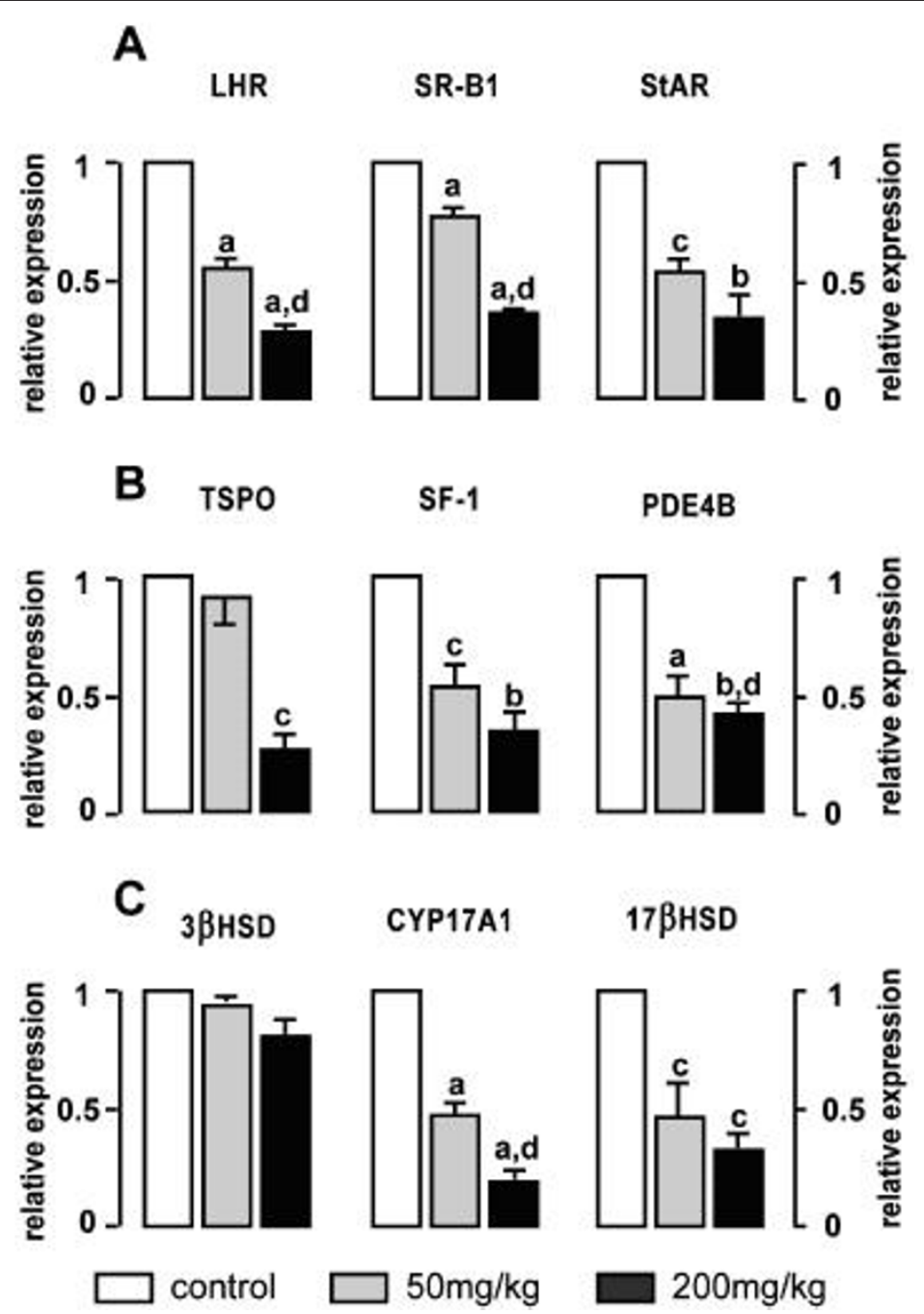

Figure 2 Effect of atrazine on gene expression. Effect on gene expression of luteinizing hormone receptor (LHR), scavenger receptor-B1(SRB1), steroidogenic acute regulatory protein (StAR), translocator protein (TSPO), steroidogenic factor-1 (SF-1), phosphodiesterase-4B (PDE4B), 3Bhydroxysteroiddehydrogenase (HSD), cytochrome P450 (CYP) 17A1, 17ß HSD in Leydig cells of control and treated rats (50 and $200 \mathrm{mg} / \mathrm{kg}$ atrazine by gavage from postnatal day 23 to 50). The transcription of LHR gene in Leydig cells of atrazine-treated rats was downregulated in a dose-dependent manner, which could be the reason for reduction in cAMP level and expression of cAMP dependent genes Reproduced with permission from [33].) 


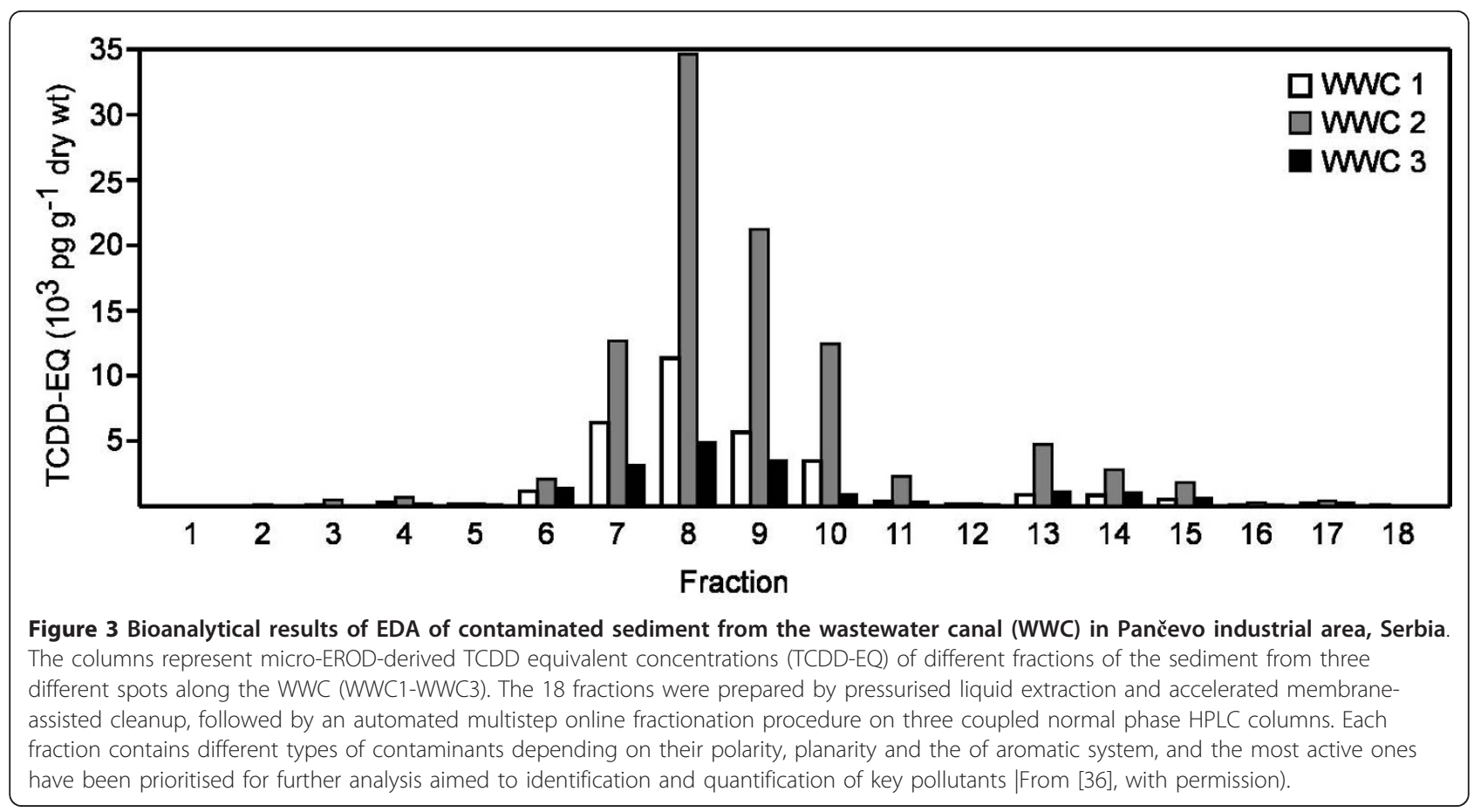

Development of the autonomous province of Vojvodina to establish the laboratory facility for Danio rerio acute and chronic ecotoxicological tests, embryotoxicity DarT and, in the near future, to introduce Gene DarT test - the latest toxicity test on $D$. rerio based on gene expression of potential marker genes.

As a direct follow-up of increasing international networking and reinforcement facilitated by REP-LECOTOX, LECOTOX participates in the project "Establishing and developing of an ecotoxicology platform in Serbia and Croatia: a focus on zebra fish (Danio rerio)" with the University of Applied Sciences, School of Life Sciences, Muttenz, Switzerland and Rudjer Bošković Institute Division for Marine and Environmental Research - Molecular Ecotoxicology, Zagreb, Croatia (2010-2012, funded by the Swiss National Scientific Foundation via SCOPES 20082012 programme). The project is directed to (a) the transfer of knowledge and expertise that will enable Serbian and Croatian partners to improve their overall research capacity, performing part of the research using zebra fish (Danio rerio) cell lines (PAC1 and ZFL) and (b) to better understanding of critical cellular, evolutionary conserved xenobiotic defence systems in aquatic organisms, using zebra fish as a model, specifically focused on the uptake of environmental chemicals and metabolites by specific transmembrane proteins, detoxification by phase I and II biotransformation enzyme systems; and finally, active elimination of xenobiotics and metabolites through specific transmembrane proteins (ABC transporters).
LECOTOX recently passed with two project proposals for the call launched by the Ministry of Science and Technological Development of the Republic of Serbia. The first one, submitted individually (Grant No. 173037), is intended to study reproductive, metabolic and developmental responses of selected model organisms and cell lines to some individual EDCs and their mixtures using different in vivo and in vitro biological models and elucidate further their mechanism of action applying newly established transcriptomics. The second proposal, submitted in co-operation with the Department of Chemistry, Biochemistry and Environmental Protection (Grant No. 172028), is focused on assessing the impact of chemical structure and different environmental matrices on bioavailability (and hence ecotoxicity) as well as efficiency of removal of selected xenobiotics and their mixtures in water treatment processes combining chemical, biological and in silica (mainly QSAR) tools. The implementation of the above mentioned projects will express the benefits of REPLECOTOX project in a full scale. The latest proposal, which can be seen as the direct follow-up of REPLECOTOX, is UNLOCKLECOTOX project proposal (Unlocking and developing the research potential of LECOTOX UNSPMF - Laboratory for Ecotoxicology, University of Novi Sad Faculty of Sciences, Serbia) has been submitted to FP 7-REGPOT-2011-1 call. If successful, the implementation of this proposal would prepare LECOTOX for some of the major challenges in the fields of ecotoxicology and chemical and ecological risk 
assessment today: (a) application of integrated testing strategies by phasing out in vivo testing in line with 3R strategy (replace, reduce, refine), promoting omic and integrating chemical, in vitro and in silico methods, and (b) development of ecologically or ecosystem-relevant risk assessment approaches and methodologies.

\section{Additional material}

Additional file 1: REP LECOTOX project compendium. The project compendium contains comprehensive description of the FP 6 funded REP LECOTOX project and the profile of LECOTOX research team.

\section{Authors' contributions}

IT drafted the manuscript and participated in the design and coordination of the FP 6 funded project described herewith. RK designed and coordinated the FP 6 project described herewith and revised the manuscript. SK designed and performed EDA study. IP designed and performed TRIAD based study. KPM designed and performed the atrazine study. SF designed and performed the study with BFRs. VD participated in transcriptomic study with D. magna. JH and BG introduced D. rerio embrio test. All authors participated in the FP 6 funded project REP LECOTOX presented herewith, read and approved the final manuscript.

\section{Competing interests}

The authors declare that they have no competing interests.

Received: 20 December 2010 Accepted: 2 February 2011

Published: 2 February 2011

\section{References}

1. Marić $D$, Tadić $R$, Milin $R$ : The influence of the gonads in the functional development of the hypothalamo-hypophyseal system of male rat. Neuroendocrinology 1973, 15:92-98.

2. Marić $D$, Kostić T, Kovačević R: Effects of acute and chronic immobilisation stress on rat Leydig cell steroidogenesis. J Steroid Biochem Mol Biol 1996, 58:351-355.

3. Kovačević R, Krsmanović L, Stojilković S, Simonović I, Marić D, Andjus RK: Effects of bromocriptine-induced hypoprolactinemia on developmental pattern of androgen and LH levels. Int J Androl 1982, 5:437-447.

4. Kovačević R, Krsmanović L, Stojilković S, Simonović I, Marić D, Andjus RK: Developmental pattern of the testicular androgen response to gonadotropin stimulation in vitro and its modification by chronic hypoprolactinemia. Int J Androl 1987, 10:773-784.

5. Kovačević R, Sarač M: Bromocriptine-induced inhibition of hydroxylase/ lyase activity in adult male rat Leydig cells. J Steroid Biochem Mol Biol 1993, 46:841-845.

6. Kostić $T$, Andrić $S$, Kovačević $R$, Marić $D$ : The effect of opioid antagonists in local regulation of testicular response to acute stress in adult rats. Steroids 1997, 62:703-708.

7. Kostić T, Andrić $S$, Kovačević R, Marić D: The effect of acute stress and opioid antagonists on the activity of NADPH-P450 reductase in rat Leydig cells. J Steroid Biochem Mol Biol 1998, 66:51-54.

8. Kostić TS, Andrić SA, Marić D, Kovačević RZ: Inhibitory effects of stressactivated nitric oxide on antioxidant enzymes and testicular steroidogenesis. J Steroid Biochem Mol Biol 2001, 75(4-5):299-306.

9. Kostić TS, Andrić SA, Marić D, Stojilković SS, Kovačević R: Involvement of inducible nitric oxide synthase in stress-impaired testicular steroidogenesis. J Endocrinol 1999, 163:409-416.

10. Kovačević R, Vojnović-Miloradov M, Teodorović I, Andrić S: Effect of PCBs on androgen production by suspension of adult rat Leydig cells in vitro. J Steroid Biochem Mol Biol 1995, 52:595-597.

11. Andrić SA, Kostić ST, Dragišić S, Andrić NL, Stojilković SS, Kovačević RZ: Acute effects of polychlorinated biphenyl-containing and -free transformer fluids on rat testicular steroidogenesis. Environ Health Perspect 2000, 108:955-959.

12. Andrić SA, Kostić TS, Stojilković SS, Kovačević RZ: Inhibition of rat testicular androgenesis by a polychlorinated biphenyl mixture Aroclor 1248. Biol Reprod 2000, 62:1882-1888.

13. Andrić S, Andrić N, Zorić S, Kostić T, Kovačević R: Effects of polychlorinated biphenyl-containing and -free transformer fluids on testicular enzyme activities. Fresenius Environmental Bulletin 2003, 12:245-249.

14. Andrić NL, Andrić SA, Zorić SN, Kostić TS, Stojilković SS, Kovačević RZ: Parallelism and dissociation in the actions of aroclor 1260-based transformer fluid on testicular androgenesis and antioxidant enzymes. Toxicology 2003, 194:65-75.

15. Andrić NL, Kostić TS, Zorić SN, Stanić BD, Andrić SA, Kovačević RZ: Effect of a PCB-based transformer oil on testicular steroidogenesis and xenobiotic-metabolising enzymes. Reprod Toxicol 2006, 22:102-110.

16. Andrić $N$, Kostić $T$, Kaišarević $S$, Fa S, Pogrmić $K$, Kovačević R: In vivo and in vitro effects of $\mathrm{PCB} 126$ and $\mathrm{PCB} 153$ on rat testicular androgenesis. Environ Toxicol Pharmacol 2008, 25:222-226.

17. Stanić $B$, Andrić N, Zorić $S$, Grubor-Lajšić $G$, Kovačević R: Assessing pollution in the Danube River near Novi Sad (Serbia) using several biomarkers in sterlet (Acipenser ruthenus L.). Ecotoxicol Environ Saf 2006, 65:395-402.

18. Dalmacija B, Prica M, Ivančev-Tumbas I, van der Kooij A, Rončević S, Krčmar D, Bikit I, Teodorović I: Pollution of the Begej Canal sediment metals, radioactivity and toxicity assessment. Environ Int 2006, 32:606-615.

19. Teodorović I, Planojević I: Daphnia magna culturing methods implications on chronic toxicity tests. Fresenius Environmental Bulletin 2008, 17:985-991.

20. Teodorović I, Bečelić M, Planojević I, Ivančev-Tumbas I, Dalmacija B: The relationship between whole effluent toxicity (WET) and chemical-based effluent quality assessment in Vojvodina (Serbia). Environ Monit Assess 2009, 158:381-392

21. Zorić S, Andrić N, Suđi J, Klanova J, Jovetić S, Kovačević R, VojinovićMiloradov M: Ethoxyresorufin-O-deethylase induction potency in sediment samples from rivers Lepenica and Morava-surrounding area of Kragujevac "hot spot". Organohalogen Compounds 2004, 66:598-602.

22. Picer M, Kovačević R, Picer N, Kobašić VH, Čalić V, Zorić S: Characterization of soil and sediment samples collected from the Zadar Area, Croatia, by GC-ECD analysis and bioassay. B Environ Contam Tox 2006, 77:687-693.

23. Kaišarević $\mathrm{S}$, Andrić $\mathrm{N}$, Bobić $\mathrm{S}$, Tričković J, Teodorović I, Vojinović Miloradov M, Kovačević R: Detection of dioxin-like contaminants in soil from the area of oil refineries in Vojvodina region of Serbia. B Environ Contam Tox 2007, 79:422-426

24. Kaišarević $S$, Hilscherova $K$, Weber $R$, Sundqvist $K L$, Tysklind $M$, Voncina $E$, Bobić S, Andrić N, Pogrmić-Majkić K, Vojinović-Miloradov M, Giesy JP, Kovačević R: Characterization of dioxin-like contamination in soil and sediments from the "hot spot" area of petrochemical plant in Pančevo (Serbia). Environ Sci Pollut R, doi 2010 10.1007/s11356-010-0418-8.

25. Streck HG, Schulze T, Brack W: Accelerated membrane-assisted clean-up as a tool for the clean-up of extracts from biological tissues. J Chromatogr A 2008, 1196-1197:33-40.

26. Lübcke-von Varel U, Streck G, Brack W: Automated fractionation procedure for polycyclic aromatic compounds in sediment extracts on three coupled normal-phase high-performance liquid chromatography columns. J Chromatogr A 2008, 1185:31-42.

27. Kovačević R, Teodorović I, Kaišarević S, Planojević I, Fa S, Dakić V, Pogrmić K, Virijević S: First REP-LECOTOX Workshop - ecotoxicogenomics: the challenge of integrating genomics/proteomics/metabolomics into aquatic and terrestrial ecotoxicology. Environ Sci Pollut R 2009, 16(Suppl 1):S130-S131.

28. Teodorović I, Kaišarević S, Planojević I, Fa S, Dakić V, Pogrmić-Majkic K, Hrubik J, Glišić B, Kovačević R: 2nd REP-LECOTOX Workshop "Trends in ecological risk assessment" University of Novi Sad, Serbia, 21-23 September 2009. Environmental Science Europe 2011, 23(6).

29. Teodorović I: Ecotoxicological research and related legislation in Serbia. Environ Sci Pollut R 2009, 16(Suppl 1):S123-S129

30. Teodorović I: Ecotoxicological research and its implications for important water management issues in the Danube River Basin. Danube News 2010 20:2-4.

31. Teodorović I: Ecotoxicology - science contributes to water management issues, Danube Watch. 2010, 1/2010. 
32. Teodorović I: REP LECOTOX project: An example of FP INCO project to strengthen ecotoxicological research in Eastern Europe, Danube News. 2010, 20, 15

33. Pogrmić K, Fa S, Dakić V, Kaišarević $S$, Kovačević R: Atrazine oral exposure of peripubertal male rats down-regulates steroidogenesis gene expression in Leydig cells. J Toxicol Sci 2009, 111:189-197.

34. Pogrmić-Majkić K, Fa S, Dakić V, Kaišarević S, Kovačević R: Up-regulation of peripubertal rat Leydig cell steroidogenesis following 24 hour in vitro and in vivo exposure to atrazine. Toxicological Sciences (on line first) 2010.

35. Fa S: Potential toxic effects of brominated flame retardants on steroidogenesis in rats. Univeristy of Novi Sad, PhD Thesis, (in preparation).

36. Kaišarević S, Lübcke-von Varel U, Orčić D, Streck G, Schulze T, Pogrmić K Teodorović I, Brack W, Kovačević R: Effect-directed analysis of contaminated sediment from the wastewater canal in Pančevo industrial area, Serbia. Chemosphere 2009, 77:907-913.

37. Kaišarević $S$, Lübcke-von Varel $U$, Orčić $D$, Streck $G$, Schulze T, Pogrmić $K$, Teodorović I, Brack W, Kovačević R: Contaminated sediment from industrial area in Serbia: further steps in effect-directed analysis. Chemospere, (In Preparation).

38. Teodorović I, Planojević I, Knežević P, Radak S, Nemet I: Sensitivity of bacterial vs. acute Daphnia magna toxicity tests to metals. Central European Journal of Biology 2009, 4:482-492.

39. Planojević I, Teodorović I, Bartova K, Tubić A, Jurca T, Kopf W, Machat J, Blaha L, Kovačević R: Wastewater canal Vojlovica, industrial complex Pančevo, Serbia - preliminary ecotoxicological assessment of contaminated sediment. J Serb Chem Soc 2011, Online first.

40. David RM, Dakić V, Williams TD, Winter MJ, Chipman JK: Gene expression in neonate and adult daphniain relation to relative susceptibility to genotoxicants. Aquatic Toxicology 2011.

doi:10.1186/2190-4715-23-5

Cite this article as: Teodorović et al: REP-LECOTOX: an example of FP 6 INCO project to strengthen ecotoxicological research in WBC (Western Balkan countries). Environmental Sciences Europe 2011 23:5.

\section{Submit your manuscript to a SpringerOpen ${ }^{\circ}$ journal and benefit from:}

- Convenient online submission

- Rigorous peer review

- Immediate publication on acceptance

- Open access: articles freely available online

- High visibility within the field

- Retaining the copyright to your article

Submit your next manuscript at $\gg$ springeropen.com 